\title{
Hutang Luar Negeri Dalam Perspektif Ekonomi Syariah
}

\author{
Cihwanul Kirom \\ Institut Agama Islam Negeri Kudus \\ Mukarrom1984@yahoo.com
}

\begin{abstract}
The purpose of this study is to find out how foreign debt law is reviewed in terms of Islamic economics. Foreign debt is among the funding sources to meet the State expenditure budget. This foreign debt is very important, especially developing countries in improving the economy. However, this debt problem has become a long debate among the people. There are people who agree that if the country adds debt, there are also those who disagree about it. Especially in terms of the applicable aspects of sharia economic law, this study reveals various theories and laws on sharia economic perspective on foreign debt. The results of this study are hadith exposure and the level of debt budgeted by the government.
\end{abstract}

Keywords: debt, foreign, Islamic economics

\begin{abstract}
Abstrak
Tujuan penelitian ini adalah untuk mengetahui bagaimana hukum hutang luar Negeri di tinjau dalam segi ekonomi syariah. Hutang luar Negeri merupakan diantara sumber pendanaan untuk memenuhi anggaran pengeluaran Negara. Hutang luar Negeri ini merupakan hal yang sangat penting terutama Negara berkembang dalam meningkatkan perekonomian. Namun, Permasalahan hutang ini menjadi perdebatan panjang di kalangan masyarakat. Ada Masyarakat yang setuju apabila Negara menambah hutang, ada juga yang tidak sepakat tentang hal itu. Apalagi ditinjau dari aspek hukum ekonomi syariah yang berlaku, maka penelitian ini mengungkapkan berbagai teori dan hukum hutang luar negeri prespektif ekonomi syariah. Hasil dari penelitian ini berupa paparan hadist dan tingkat hutang yang di anggarkan oleh pemerintah.
\end{abstract}

Keywords: hutang, luar negeri, ekonomi syariah

\section{PENDAHULUAN}

Hutang luar negeri merupakan salah satu sumber pembiayaan pembangunan yang sangat signifikan bagi negara berkembang. Namun demikian, hasil studi tentang dampak hutang terhadap pembangunan ekonomi menunjukkan hasil yang berbeda-beda. Beberapa ilmuwan memperoleh kesimpulan bahwa hutang luar negeri justru telah menimbulkan perlambatan pertumbuhan ekonomi bagi negara-negara penghutang besar, sementara studi lain menyimpulkan sebaliknya-yaitu hutang luar negeri menjadi salah satu faktor yang secara signifikan mendorong pertumbuhan ekonomi negara-negara penghutang. (Chowdurry, 1997: 337)

Banyak negara sedang berkembang (NSB) yang kini telah masuk dalam perangkap hutang (debt trap), dan akhirnya hanyut dalam lingkaran 
ketergantungan hutang (debt overhang hypothesis). (Kaminsky, 1996: 221) Dalam konteks argumentasi ini, patut dipertanyakan kembali relevansi dan urgensi hutang luar negeri dalam pembiayaan negara-negara berkembang.

Bagi Indonesia, badai krisis yang menerpa tahun 1990-an, sempat membuat porak-poranda perekonomian Indonesia. Sebagai negara stabil dengan pertumbuhan ekonomi yang fantastis, ternyata begitu ditimpa badai krisis, seluruh bangunan ekonominya runtuh, persatuan nasional rapuh terancam disintegrasi bangsa seperti Yugoslavia dan negara-negara kawasan Balkan. Krisis ekonomi berkepanjangan dan lambannya pemulihan ekonomi, menunjukkan kerapuhan fondasi ekonomi Indonesia yang selama ini dibangun. Praktek monopoli, konglomerasi dan ekonomi kapitalistik mematikan usaha-usaha ekonomi kerakyatan, memperluas kesenjangan ekonomi dan kecemburuan sosial. Kondisi ini semakin diperparah oleh budaya gemar berhutang dan mempermanis istilah hutang luar negeri dengan bantuan luar negeri. Celakanya lagi hutang luar negeri/ bantuan luar negeri dari negara-negara donor, dan lembaga-lembaga keuangan internasional seperti IMF dan Bank Dunia banyak yang dikorup oleh orang-orang yang tidak bertanggungjawab. Tingkat kebocoran ini cukup signifikan, menurut begawan ekonomi Sumitro Djojohadikusumo, mencapai 30\% dari total anggaran pembangunan. (Edy Suandi Hamid, 2000: 67)

Jefrey A. Winters, seorang ekonom dari Northwestern University AS mengemukakan bahwa paling tidak sepertiga dari bantuan (pinjaman) Bank Dunia untuk Indonesia bocor di birokrasi Indonesia. Dalam hasil survey Transparancy International terhadap 52 negara, Indonesia menempati peringkat ke-7 dan di antara negara ASEAN, berada pada peringkat pertama. (Edy Suandi Hamid, 2000: 74-75)

Jumlah hutang luar negeri Indonesia menempati peringkat ke-5 di antara negara dunia ketiga, setelah Meksiko, Brazil, India dan Argentina. (Roem Topatimasang, 1999: 8) Akibat krisis ekonomi yang sangat parah ini, menjadikan Indonesia sebagai negara dengan rasio stock hutang per GDP tertinggi di dunia, mengalahkan negara-negara yang selama ini terkenal sebagai penghutang terbesar, seperti Meksiko, Brazil dan Argentina. (Roem Topatimasang, 1999: 8)

Berdasarkan data yang dikeluarkan oleh Departemen Keuangan, nilai total hutang pemerintah pusat dalam rupiah mengalami peningkatan setiap tahun dari $\operatorname{Rp~1.234,28~triliun~pada~tahun~} 2000$ menjadi Rp 1.659,79 triliun per Juli 2010, dan pada tahun 2011 diperkirakan jumlahnya akan mencapai Rp 1.807, dilihat dari persentasenya terhadap PDB, memang rasionya cenderung mengecil setiap tahun dari sekitar 89 persen pada tahun 2000 menjadi 26 persen per Juli 2010. ini menandakan bahwa laju pertumbuhan PDB lebih pesat dibandingkan laju peningkatan jumlah 
hutang. Ini bisa memberi kesan bahwa, paling tidak pada tingkat makro, tingkat efektivitas dari penggunaan hutang pada perekonomian nasional terus membaik. (Tulus T.H. Tambunan, 2012: 262)

Persoalan hutang luar negeri ini bila tidak diselesaikan dengan baik akan dapat menghambat pemulihan ekonomi dan menjatuhkan martabat bangsa Indonesia di mata dunia internasional. Hal inilah yang menarik penulis untuk lebih jauh mengkaji dan menuangkan gagasan "Hutang Luar Negeri Indonesia, Perspektif Ekonomi Syariah"

\section{KAJIAN LITERATUR}

Hutang adalah semua kewajiban keuangan perusahaan kepada pihak-pihak lain yang belum terpenuhi, dimana hutang ini merupakan sumber dana atau modal suatu perusahaan. (Roem Topatimasang, 1999: 8)

Hutang merupakan perwujudan dari suatu pinjaman yang dilakukan oleh pemerintah. Biasanya transaksi hutang atau pinjaman ini terjadi, manakala pendapatan negara dalam keadaan terbatas, dan tidak imbang dengan meningkatnya kebutuhan akan anggaran pembangunan. Dengan kata lain, penerimaan negara yang ada masih belum mampu berpacu dengan kebutuhan pengeluaran negara yang diinginkan, atau pemerintahan tidak punya uang yang cukup. Setidaknya, kesalahan tersebut tidak harus dibayar dengan berhutang. (Munrokhim Misanam, 2000: 12)

Sebenarnya untuk menambah pos penerimaan negara ada dua cara yaitu; menarik dana dari dalam negeri berupa pajak atau surat hutang, dan menarik dana dari luar negeri dalam bentuk investasi atau pinjaman. Penarikan dana berupa pajak yang belum dibayarkan oleh wajib pajak seringkali menghambat pendapatan pemerintah. Idealnya, kesadaran wajib pajak tinggi atau kalau tidak dilakukan penarikan oleh pihak pemerintah. Daripada pemerintah lebih memilih menarik dana dari luar negeri. (Umar Juaro, 2004: 42)

Mencermati fenomena hutang, dan supaya stabilitas perekonomian tetap terjaga agar defisit anggaran pendapatan dan belanja Negara tidak melampaui batas yang aman. Maka pengelolaaan hutang perlu dilakukan, agar krisis ekonomi yang pernah terjadi tidak terulang kembali di Indonesia. Sehingga perencanaan, implementasi dan pengendalian atas pinjaman menjadi sangat penting adanya.

Hutang luar negeri Indonesia yang disajikan dalam makalah ini adalah hutang luar negeri pemerintah, bank sentral dan swasta. Hutang luar negeri bank sentral adalah hutang yang dimiliki oleh Bank Indonesia, yang diperuntukkan dalam rangka mendukung neraca pembayaran dan cadangan devisa. Selain itu juga terdapat hutang kepada pihak bukan 
penduduk yang telah menempatkan dananya pada Sertifikat Bank Indonesia (SBI), dan hutang dalam bentuk kas dan simpanan serta kewajiban lainnya kepada bukan penduduk. Hutang luar negeri swasta adalah hutang luar negeri penduduk kepada bukan penduduk dalam valuta asing dan atau rupiah berdasarkan perjanjian hutang (loan agreement) atau perjanjian lainnya, kas dan simpanan milik bukan penduduk, dan kewajiban lainnya kepada bukan penduduk.

Hutang terdiri atas hutang lancar (hutang jangka pendek) dan hutang tidak lancar (hutang jangka panjang). (Munrokhim Misanam, 2000:

15) Hutang dapat diklasifikasikan menjadi dua jenis, yaitu:

1. Hutang lancar (hutang jangka pendek)

Hutang lancar yaitu kewajiban keuangan perusahaan yang pelunasannya atau pembayarannya akan dilakukan dalam jangka pendek (satu tahun sejak tanggal neraca) dengan menggunakan aktiva lancar yang dimiliki oleh perusahaan.

2. Hutang tidak lancar (hutang jangka panjang)

Hutang tidak lancar yaitu kewajiban keuangan yang jangka waktu pembayarannya (jatuh temponya) masih jangka panjang (lebih dari satu tahun sejak tanggal neraca).

Hutang swasta meliputi hutang bank dan bukan bank.Hutang luar negeri bukan bank terdiri dari hutang luar negeri Lembaga Keuangan Bukan Bank (LKBB) dan Perusahaan Bukan Lembaga Keuangan termasuk perorangan kepada ihak bukan penduduk. Termasuk dalam komponen hutang luar negeri swasta adalah hutang luar negeri yang berasal dari penerbitan surat berharga di dalam negeri yang dimiliki oleh bukan penduduk.

\section{Kebijakan Hutang}

Kebijakan hutang merupakan kebijakan pendanaan yang dilakukan oleh pihak manajemen perusahaan dalam rangka memperoleh sumber pendanaan untuk membiayai aktivitas operasional perusahaan.Kebijakan hutang juga merupakan salah satu kebijakan pendanaan yang berasal dari eksternal perusahaan.

Myers dan Maljuf dalam Faisal menjelaskan bahwa keterkaitan antara kebijakan hutang dengan profitabilitas perusahaan yang menyatakan bahwa perusahaan yang lebih menguntungkan akan menurunkan hutangnya. Perusahaan lebih memilih membiayai perusahaan mereka dengan menggunakan sumber dana yang diperoleh dari internal perusahaan. (Munrokhim Misanam, 2000: 16)

Kebijakan hutang memiliki pengaruh pendisiplinan perilaku manajer. Hutang akan mengurangi agency conflict dan meningkatkan nilai perusahaan. Peningkatan hutang meningkatkan leverage sehingga 
meningkatkan kemungkinan kesulitan-kesulitan keuangan atau kebangkrutan. Kekhawatiran akan kebangkrutan mendorong manajer agar efisien, sehingga memperbaiki biaya agensi. Hutang memaksa perusahaan membayar pokok hutang dan bunga sehingga mengurangi free cash flow dan menurunkan insentif manajer untuk berperilaku memuaskan diri sendiri.

Masalah hutang luar negeri sebagai sumber pembiayaan pembangunan (deficit budged) telah menjadi perdebatan klasik, baik dalam tataran teoritis maupun praktis. Dalam pemikiran Rostow, posisi hutang luar negeri dianggap sebagai the missing link dalam mata rantai pembangunan ekonomi. Dalam dunia praktis, hutang luar negeri merupakan vicious cyrcle dalam pembangunan, khususnya negara-negara berkembang. Tercatat beberapa kali dunia mengalami debt crisis yang hebat, misalnya tahun 1930-an, 1980-an, 1980-an dan 1990-an hingga saat ini. Penyelesaian hutang luar negeri masih merupakan problematika yang kompleks dan rumit untuk dipecahkan. (D.J. Rchbini, 29)

Dalam penjelasan teori-teori konvensional, setidaknya terdapat dua teori yang dapat menjelaskan tentang urgensi hutang luar negeri bagi pembiayaan pembangunan. Teori pertama mengatakan bahwa hutang luar negeri, seperti halnya investasi asing, diperlukan untuk menutup saving gap dalam terminologi kelompok Neo-Klasik. (Roem Topatimasang, 1999: 67) Jadi dalam hal ini hutang luar negeri dibutuhkan karena domestic saving tidak mencukupi untuk pembiayaan pembangunan. Sebenarnya untuk menutup saving gap dapat dilakukan dalam dua bentuk, yaitu debt creating flow dan non debt creating flow. DCF dapat berupa hutang bilateral maupun multilateral, sedang NDCF berupa penanaman dan penyertaan modal seperti Foreign Direct Investment (FDI), short term capital dan long term capital. Teori yang kedua menjelaskan fenomena hutang luar negeri dari sisi neraca pembayaran, dimana ia merupakan salah satu account pada neraca modal, yang berfungsi mengakomodasikan kepentingan neraca berjalan yang bersifat otonom. Jadi bila neraca berjalan mengalami defisit, maka akan dikompensasikan dengan hutang luar negeri dalam neraca modal. Dalam konteks ini hutang luar negeri dapat berfungsi sebagai gap filling, yaitu mengisi gap akibat defisit neraca berjalan. (Endy Suandi Hamid, 2000: 112)

\section{Penyebab Timbulnya Hutang Luar Negeri}

Dari perspektif negara donor setidaknya ada dua hal penting yang dianggap memotivasi dan melandasi bantuan luar negeri ke negara-negara debitor. Kedua hal tersebut adalah motivasi politik (political motivation) dan motivasi ekonomi (economi motivation), dimana keduanya mempunyai keterkaitan yang sangat erat yang satu dengan yang lainnya. (Faisal Basri, 2002: 101) 
Motivasi pertama inilah yang kemudian menjadi acuan bagi AS untuk menguncurkan dana bantuan dalam merekonstruksi kembali perekonomian Eropa Barat setelah hancur saat PD II, dan program ini dikenal dengan nama Marshall Plan. (Tulus Tambunan, 2009: 89) Kesimpulan kita cukup sederhana, yaitu bahwa bantuan luar negeri pertama-tama harus dilihat sebagai tanga panjang kepentingan negaranegara donor. Motivasinya condong berbeda tergantung situasi nasional, dan bukan semata-mata dikaitkan dengan kebutuhan negara penerima yang secara potesial berbeda-beda antara negara yang satu dengan negara yang lainnya.

Sedangkan motivasi ekonomi sebagai landasan kedua yang digunakan dalam memberikan bantuan, setidak-tidaknya tercermin dari 4 argumen penting :

1. Argumen pertama didasari oleh two gap model dimana negara-negara penerima bantuan khususnya negara-negara berkembang mengalami kekurangan dalam mengakumulasi tabungan domestik sehingga tabungan-tabungan yang ada tidak mampu memenuhi kebutuhan akan tingkat investasi yang dibutuhkan dalam proses memicu pertumbuhan ekonomi. Dan pada sisi lain adalah kekurangan yang dialami oleh negara-negara yang bersangkutan dalam memenuhi nilai tukar asing (foreign exchange) untuk membiayai kebutuhan impor. Dengan demikian untuk menutupi kedua kekurangan tersebut maka andalannya adalah bantuan luar negeri.

2. memfasilitasi dan mempercepat proses pembangunan dengan cara meningkatkan pertambahan tabungan domestik sebagai akibat dari pertumbuhan yang lebih tinggi (growth and saving). Karena tinggunya pertumbuhan di negara-negara berkembang akan turut meningkatlkan atau berkorelasi positif terhadap kenaikan keuntungan yang bisa dinikmati di negara-negara maju.

3. Technical assistance, yang merupakan pendamping dari bantuan keuangan yang bentuknya adalah transfer sumber daya manusia tingkat tinggi kepada negara-negara penerima bantuan. Hali ini harus dilakukan untuk menjamin bajhwa aliran dana yang masuk dapat digunakan dengan sangat efisien dalam proses memicu kenaikan pertum buhan ekonomi.

4. Absorptive capacity, yakni dalam bentuk apa dana tersebut akan digunakan. Terlepas dari faktor-faktor yang dikemukakan di atas ada satu hal lagi yang perlu diingat bahwa faktor pendorong da faktor penarik (push and pull factor) adalah dua kata yang menentukan terjadinya perpindahan modal ke negara-negara berkembang. Faktorfaktor ini tentu saja perpaduan antar motif ekonomi dan politik yang 
menjadi pertimbangan utama bagi investor yang rasional. (Boediono, 2008: 76)

Banyak pihak yang mengkhawatirkan kondisi pinjaman luar negeri pemerintah maupun pinjaman swata cukup beralasan. Angka statistik pinjaman luar negeri Indonesia, baik pemerintah maupun swasta memang masih menunjukkan tingginya kewajiban Indonesia dalam membayar kembali pokok dan bunga pinjaman luar negeri. Beberapa indikator dalam mengukur beban hutang, seperti :

1. Debt service Ratio (DSR) yang merupakan perbandingan antara kewajiban membayar untang dan cicilan untang luar negeri dengan devisa hasil ekspor. Ambang batas aman angka DSR lazimnya menurut para ahli ekonomi adalah $20 \%$. Lebih dari itu, hutang sudah dianggap mengundang cukup banyak kerawanan.

2. Debt to Export Ratio yang merupakan rasio hutang terhadap ekspor. Bank dunia menetapkan bahwa suatu negara dikategorikan sebagai negara penghutang berat, jika negara yang bersangkutan memiliki Debt to Export Ratio yang lebih besar dari $220 \%$.

3. Debt to GDP Ratio yang merupakan rasio hutang terhadap PDB. Rasio hutang terhadap PDB dapat dilihat sebagai kriteria mengecek kesehatan keuangan suatu negara, dimana rasio di atas 50\% menunjukkan bahwa pinjaman luar negeri Indonesia membenahi lebih dari 50\% Pendapatan Nasional. (Basri, 201)

Pinjaman luar negeri tersebut tidak semua diberikan dalam bentuk rupiah atau tepatnya mata uang asing tertentu tetapi dalam bentuk bantuan proyek dan bantuan program.Bantuan proyek diberikan dalam bentuk pinjaman berupa peralatan-peralatan, barang-barang ataupun jasa (konsultan asing), sedangkan bantuan program diberikan dalam bentuk bantuan tunai.

\section{Sumber Hutang Luar Negeri Indonesia}

Hingga tahun 1997, pembangunan di Indonesia selalu dipuji oleh lembaga-lembaga keuangan internasional. Bahkan dalam laporan Bank Dunia pada bulan Juni 1997, Indonesia mendapat predikat keajaiban atau negara yang pertumbuhannya ajaib. (Kaminsky, 1996) Sebelumnya jatuhnya Orde Baru, Bank Dunia selalu memuji prestasi pembangunan ekonomi Indonesia. Bahkan posisi Indonesia ditempatkan sebagai salah satu negara berkembang yang sukses pembangunan ekonominya, tanpa melihat proses pembangunan itu telah merusak dan menghabiskan sumber daya alam yang ada, dan melilitkan Indonesia pada hutang luar negeri yang sangat besar. (Kaminsky, 1996: 180)

Satu hal penting yang dilupakan adalah bahwa semua keberhasilan itu dicapai dengan hutang, sehingga menjadi bumerang ketika Indonesia 
diterpa krisis pada tahun 1997. Seluruh bangunan ekonomi runtuh, perusahaan-perusahaan bangkrut, pengangguran meledak, kemisikinan meningkat, sementara beban hutang luar negeri semakin berat.

Dalam jangka pendek, hutang luar negeri sangat membantu pemerintah Indonesia dalam upaya menutup defisit anggaran pendapatan dan belanja negara, akibat pembiayaan pengeluaran rutin dan pengeluaran pembangunan yang cukup besar. Dengan demikian, laju pertumbuhan ekonomi dapat dipacu sesuai dengan target yang telah ditetapkan sebelumnya. Tetapi dalam jangka panjang, ternyata hutang luar negeri pemerintah tersebut dapat menimbulkan berbagai persoalan ekonomi di Indonesia.

Demikian yang dikatakan oleh Umar Juoro bahwa bukan substansi dari hutang luar negeri tersebut yang bersifat investasi atau pengeluaran pemerintah yang berpengaruh terhadap pertumbuhan ekonomi, tapi pada masalah pengalokasian dari dana tersebut yang proporsional atau tidak. Kemudian yang dalam jangka panjang jumlah yang harus dibayarkan kembali lebih banyak jumlahnya dari yang dipinjam sehingga menimbulkan masalah baru terhadap keseimbangan keuangan Negara.

Sampai saat ini, Indonesia masih memiliki pinjaman luar negeri. Per Januari 2017, hutang luar negeri pemerintah Indonesia (baik bilateral maupun multilateral) tercatat Rp 728,15 triliun, naik tipis dari akhir 2016 yang sebesar Rp 728,08 triliun. Secara bilateral, Jepang, Prancis, dan Jerman masih menjadi kreditur terbesar hutang Indonesia. Sementara secara multilateral, Indonesia masih meminjam dari Bank Dunia, Bank Pembangunan Asia (ADB), dan Bank Pembangunan Islam (IDB). (Finance Detik, 2018)

Hutang luar negeri Indonesia periode 2007-2016 juga berfluktuasi, namun masih memperlihatkan trend naik. Hal dikarenakan keharusan pemerintah untuk melakukan pinjaman kembali untuk melakukan pembayaran hutang yang sudah jatuh tempo beserta bunganya. Bahkan pada tiga tahun terakhir, posisi hutang luar negeri Indonesia terus mengalami kenaikan. Ini menandakan bahwa pemerintah Indonesia masih menjadikan hutang luar negeri sebagai salah satu alternatif guna melakukan proses pembangunan.

\section{PEMBAHASAN}

\section{Hutang Luar Negeri dalam Prespektif Ekonomi Syariah}

Secara bahasa al-qardh berarti al-qoth' (terputus). Harta yang diutangkan kepada pihak lain dinamakan qardh karena ia terputus dari pemiliknya. (Nasrun Haroen, 2000: 170) Adapun yang dimaksud dengan utang piutang adalah memberikan sesuatu kepada seseorang dengan perjanjian dia akan membayar yang sama dengan itu. (Basri, 2003: 60) 
Pengertian "sesuatu" dari definisi diatas mempunyai makna yang luas, selain dapat berbentuk uang, juga bisa saja dalam bentuk barang, asalkan barang tersebut habis karena pemakaian. (Chairuman Pasaribu, 136) Pengertian al-qardh menurut istilah adalah penyerahan (pemilikan) harta al-misliyat kepada orang lain untuk ditagih pengembaliannya, atau dengan pengertian lain, suatu akad yang bertujuan untuk menyerahkan harta misliyat kepada pihak lain untuk dikembalikan yang sejenis dengannya. (Adiwarman Karim, 2007: 52)

Secara syari'i menurut Hanafiyah, adalah harta yang memiliki kesapadanan yang diberikan untuk anda tagih kembali dengan nilai sepadan. Transaksi Qardh diperbolehkan oleh para ulama berdasarkan hadist riwayat ibnu Majah dan ijma para ulama. Sungguhpun demikian Allah SWT mengajarkan kepada kita agar meminjamkan sesuatu bagi agama Allah SWT. Sebagaimana firman Allah dalam Qs. Al-Hadid (57) : 11, sebagai berikut :

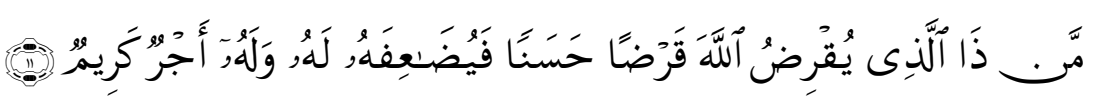

Terjemahnya: Siapakah yang mau meminjamkan kepada Allah pinjaman yang baik, Maka Allah akan melipat-gandakan (balasan) pinjaman itu untuknya, dan Dia akan memperoleh pahala yang banyak.

Hadist dari Sunnah Rasul Ibnu Mas'ud meriwayatkan bahwa Nabi Muhammad SAW bersabda: Bukan seorang muslim (mereka) yang meminjamkan muslim (lainnya) dua kali kecuali yang satunya adalah (senilai) shadaqah. (As-Shadaqah, 2419) Ijma para ulama telah menyepakati bahwa qardh boleh dilakukan, kesepakatan para ulama didasari tabiat manusia yang tidak bisa hidup tanpa pertolongan dan bantuan saudaranya.

Utang piutang merupakan salah satu bentuk mu'amalah yang bercorak ta'awun (pertolongan) kepada pihak lain untuk memenuhi kebutuhannya. Sumber ajaran Islam sangat kuat menyerukan prinsip hidup gotong royong seperti ini. Bahkan al-Qur'an menyebut utangpiutang untuk menolong atau meringankan orang lain yang membutuhkan dengan istilah "mengutangkan kepada Allah dengan utang baik." (Ghufron, 2002: 171)

Disyaratkan untuk sahnya pemberian utang ini bahwa pemberi utang adalah orang yang boleh mengeluarkan sedekah. Maka, seorang wali (pengasuh) anak yatim tidak boleh memberikan utang dari harta anak yatim yang ia asuh tersebut. Disyaratkan juga diketahuinya jumlah dan ciri-ciri harta yang dipinjamkan, agar dapat dikembalikan kepada pemiliknya. Dengan demikian, piutang tersebut menjadi utang di tangan orang yang meminjam, dan ia wajib mengembalikannya ketika mampu dengan tanpa menunda-nundanya. 
Akad utang piutang dimaksudkan untuk mengasihi di antara sesama manusia, menolong mereka dalam menghadapi berbagai urusan, dan memudahkan denyut nadi kehidupan. Akad utang piutang tidak bukan salah satu sarana untuk memperoleh penghasilan dan bukan pula salah satu cara untuk mengeksploitasi orang lain. Oleh karena itu, orang yang berutang tidak boleh mengembalikan kepada orang yang memberi utang kecuali apa yang telah di utang nya atau serupa dengannya.

Hal ini sesuai dengan kaidah fikih, "Setiap piutang yang mendatangkan manfaat adalah riba." Keharaman ini berlaku jika manfaat dari akad utang piutang disyaratkan atau disesuaikan dengan tradisi yang berlaku. Jika manfaat ini tidak disyaratkan dan tidak dikenal dalam tradisi, maka orang yang berutang boleh membayar utangnya dengan sesuatu yang lebih baik kualitasnya dari apa yang di utang nya, atau menambah jumlahnya, atau menjual rumahnya kepada orang yang memberi utang. (Sayyid Sabiq, 2009: 217)

Kalau kita telaah lebih mendalam ada beberapa hal yang menjadikan utang Luar negeri menjadi bathil. Pertama Utang luar negeri tidak dapat dilepaskan dari bunga (riba). Padahal Islam dengan tegas telah mengharamkan riba itu sebagaimana Allah SWT berfirman dalam Qs. alBaqarah (2) : 275 .

Utang yang terkait dengan individu hukumnya mubah, untuk itu setiap individu boleh berutang kepada siapa saja yang dikehendaki, berapa yang diinginkan baik kepada sesama rakyat maupun kepada orang asing, seperti yang diungkapkan dari hadist :

Dari Rafi' berkata, Nabi saw meminjam lembu muda, kemudian Nabi saw menerima unta yang bagus, lalu beliau menyuruhku melunasi utang lembu mudanya kepada orang itu. Aku berkata "Aku tidak mendapati pada unta itu selain unta yang ke empat kakinya bagus-bagus. Beliau bersabda berikan saja ia kepadanya, sebab sebaik-baik manusia adalah mereka yang paling baik ketika melunasi utangnnya.

Dalam Islam, konsep utang terdiri dari dua, utang melalui pinjaman dan utang melalui pembiayaan. (Abdul Mannan, 1992: 27) Utang pinjaman bermakna utang yang muncul disebabkan oleh pinjaman, baik pinjaman barang atau pinjaman uang.

Pinjaman ini akan dibayar kembali dengan jenis yang sama, pada masa yang telah disepakati dengan jumlah yang sama. Dalam syariat Islam utang pinjaman secara zahir bukan termasuk pada usaha pengembangan modal, karena utang melalui peminjaman merupakan salah satu bentuk bantuan yang sifatnya tolong menolong.

Sedangkan utang melalui kontrak pembiayaan atau jual beli, seperti utang yang timbul karena adanya transaksi perdagangan, adalah bentuk utang yang berbeda dengan utang secara pinjaman, karena utang dalam 
bentuk ini mengindikasikan adanya pemindahan hak milik kepada orang lain. Kemudian pembayaran pokok utang dilakukan kembali secara tertunda pada masa yang disetujui. (Yusuf Qardhawi, 1997: 111)

Riba Nasi'ah disebut juga Riba Duyun, yaitu riba yang timbul akibat utang piutang yang tidak memenuhi kriteria untung muncul bersama resiko (al ghunmu bil ghurmi) dan hasil usaha muncul bersama biaya (al kharaj bi dhaman). Transaksi semisal ini mengandung pertukaran kewajiban menanggung beban, hanya karena berjalannya waktu. Nasi'ah adalah penangguhan penyerahan atau penerimaan jenis barang ribawi yang dipertukarkan dengan jenis barang ribawi lainnya. Riba nasi 'ah muncul karena adanya perbedaan, perubahan atau tambahan antara barang yang diserahkan hari ini dengan barang yang diserahkan kemudian. (Yusuf Qardhawi, 1997: 111)

Jadi al ghunmu (untung) muncul tanpa adanya al ghurmi (resiko), hasil usaha (al kharaj) muncul tanpa adanya biaya (dhaman) al ghunmu dan al kharaj muncul hanya dengan berjalannya waktu. Padahal dalam bisnis selalu ada kemungkinan untung dan rugi. Memastikan sesuatu yang diluar wewenang manusia adalah bentuk kezaliman.

Padahal justru itulah yang terjadi dalam riba nasi'ah, yakni terjadi perubahan sesuatu yang seharusnya bersifat uncertain (tidak pasti) menjadi certain (pasti). Pertukaran kewajiban menanggung beban (exchange of liability) ini, dapat menimbulkan tindakan zalim terhadap salah satu pihak, kedua pihak, dan pihak-pihak lain. Pendapat Imam Sarakhzi akan memperjelas hal ini. Riba adalah tambahan yang disyaratkan dalam transaksi bisnis tanpa adanya padanan (iwad) yang dibenarkan syariah atas penambahan tersebut. (Imam Sarakhsi, 109)

Menurut salah seorang pengamat ekonomi Islam, Said Sa'ad Marthon "Riba nasi'ah adalah tambahan yang disyaratkan yang diambil oleh orang yang meminjamkan atas adanya perbedaan waktu tanpa adanya transaksi pembanding".

Riba nasi'ah merupakan bentuk riba yang banyak terjadi di masa jahiliyyah. Dalam prakteknya, ada beberapa dampak negatif yang ditimbulkan oleh riba, yaitu:

1. Riba dapat menumbuhkan rasa permusuhan di antara individu dan melemahkan nilai sosial dan kekeluargaan. Selain itu, riba dapat, menimbulkan eksploitasi dan tindak kezhaliman pada pihak tertentu.

2. Menumbuhkan sikap pemalas bagi orang yang mempunyai modal, dimana dia mampu mendapatkan uang banyak tanpa adanya sebuah usaha yang nyata.

3. Mendorong manusia untuk menimbun harta sambil menunggu adanya kenaikan interest rate. 
4. Menimbulkan sifat elitisme dan jauh dari kehidupan masyarakat. Selain itu, mereka hanya mementingkan interest yang akan didapatkan tanpa melihat dan memperhatikan kesenjangan dalam kehidupan masyarakat.

5. Membuat manusia lupa akan kewajiban hartanya, seperti infaq, sedekah dan zakat.

6. Medorong manusia untuk melakukan tindak kezhaliman dan eksploitasi terhadap orang lain, baik pinjaman yang bersifat produktif maupun konsumtif. (Nurul Huda, 2008: 48)

Nabi Muhammad SAW mempunyai utang dan membayarnya dengan cara yang baik, bunyi hadistnya sebagai berikut: "Dari Abu Hurairah ia berkata: "Nabi mempunyai utang kepada seseorang, (yaitu) seekor unta dengan usia tertentu. Orang itupun datang menagihnya. (Maka) beliaupun berkata, "Berikan kepadanya" kemudian mereka mencari yang seusia dengan untanya, akan tetapi mereka tidak menemukan kecuali yang lebih berumur dari untanya. Nabi (pun) berkata: "Berikan kepadanya", dia pun menjawab, "Engkau telah menunaikannya membalas dengan setimpal". Maka Nabi bersabda, "Sebaik-baik kalian adalah orang yang paling baik dalam pengembalian (utang)". Perspektif ekonomi Islam jelas melarang praktek riba. Apapun motifnya, besarannya, maupun keperluannya. (HR. Bukhari, 843: 2263)

Kebijakan hutang luar negeri, yang dimaksudkan untuk mendorong pertumbuhan ekonomi, dengan ratusan bahkan ribuan proyek yang terlibat di dalamnya pasti tidak bisa terhindarkan sebagai sasaran rente ekonomi. Jadi, pembuat disain kebijakan ekonomi bagaikan menciptakan mobil dengan "pedal gas" yang dapat dipacu dengan cepat. Perumpamaan itu dapat terlihat dari rekayasa pertumbuhan ekonomi yang cepat berbasis hutang luar negeri dan dilanjutkan dengan ekploitasi sumber daya alam secara berlebihan untuk mengejar "setoran" hutang. (D.J. Rachbini, 38)

Namun demikian, teknokrat para pembuat rancangan kebijakan ekonomi tadi lupa membuat "rem" pengendali yang baik. Akhirnya ekonomi Indonesia betul-betul terperangkap hutang yang menggiring ke jurang krisis moneter dan kemudian menular ke dalam seluruh sistem ekonomi, yang sebenarnya rentan. Krisis multidimensi lanjutannya telah menyebabkan ongkos sosial-politik yang tinggi.Bahkan biaya kemanusiaan yang terjadi juga sangat luar biasa mahal dan terpaksa harus dibayar oleh bangsa ini, yang tidak mungkin tertutupi oleh nilai tambah dari pertumbuhan ekonomi yang tercipta selama ini.

Dampak desain kebijakan hutang luar negeri tersebut telah menyodok aspek-aspek non ekonomi, terutama kerusakan birokrasi, iklim usaha, perburuan rente, inefisiensi, dan sebagainya. Kerusakan aspek non ekonomi ini, baik kelembagaan maupun perilaku aktor-aktor ekonomi, jauh lebih besar biaya sosialnya daripada aspek ekonomi itu sendiri. 
Bahkan pada pertengahan tahun 1980-an itu pertumbuhan hutang luar negeri terus berlangsung dan justeru semakin besar. Ini menunjukkan bahwa Indonesia sudah semakin terjerat dalam perangkap hutang luar negeri (debt trap). Gejala ini berlangsung sejalan dengan semakin besarnya pelarian modal negatif ke luar negeri karena pembayaran cicilan pokok dan bunga hutang sudah lebih besar dari jumlah hutang baru yang diterima. (D.J. Rachbini, 38)

Transaksi hutang luar negeri pemerintah telah menjadi bencana bagi perekonomian nasional ketika terbukti dari akumulasi yang besar dari pembayaran cicilan pokok dan bunganya. Aliran modal keluar melalui transaksi hutang ini telah menyebabkan kehilangan kesempatan investasi (oppurtunity lost) sehingga daya dorong fiskal secara langsung dari tahun ke tahun mengalami penurunan. Kebanyakan penerimaan pemerintah dari pajak masuk ke dalam pengeluaran rutin, yang kebanyakan dipakai untuk membayar hutang luar negeri. Kebijakan hutang luar negeri Indonesia akhirnya memang menjadi catatan sejarah ekonomi yang buruk dan sekaligus dapat dicatat sebagai suatu kecelakaan sejarah.Sampai pada kejadian ini, pemerintah tetap merasa santai seolah-olah tidak terjadi apapun dan tidak ada upaya yang signifikan untuk mengurangi hutang luar negeri. Tidak ada perubahan kebijakan yang mengantisipasi dengan cepat permasalahan hutang luar negeri ini sehingga terus menumpuk tanpa penyelesaian. Rutinitas perencanaan fiskal terus dijalankan tanpa makna yang berarti untuk mengurangi ketergantungan terhadap hutang luar negeri tersebut. Namun, akhirnya muncul kesadaran ketika semuanya sudah terlambat, penyakit sudah terlanjur menjadi akut dan kronis, sehingga sulit rasanya untuk bisa keluar dari cengkeraman hutang luar negeri.

Soal hutang luar negeri, Abdurrahaman al-Maliki mengungkap lima bahaya besar yang jelas-jelas tampak di depan mata yakni; Pertama, sesungguhnya hutang luar negeri untuk pendanaan proyek-proyek milik negara adalah hal yang berbahaya terutama terhadap eksistensi negara itu sendiri. Akibat lebih jauh adalah membuat masyarakat negara tersebut makin menderita karena ini adalah jalan untuk menjajah suatu negara. Seperti kita mafhum bahwa Mesir dijajah Inggris melalui jalur hutang, begitu pula Tunisia di cengkram Perancis melalui jalur yang sama yaitu hutang. Begitu pula negara Barat membentangkan hegemoninya terhadap negara Utsmaniyah pada akhir masa kekuasaannya melalui jalur hutang. Karena dengan hutang yang menumpuk Daulah khilafah Utsmaniyah yang ditakuti oleh Eropa selama 5 abad, sejak sultan Muhammad al-Fatih menaklukan konstantinopel pada tahun 1453, akhirnya menjadi negara yang lemah, tak berdaya (sebutan daulah khilafah kala itu adalah the Sick man-manusia yang sakit). Dimana akibatnya dimanfaatkan oleh Gerakan 
Zionis International, Theodore Hertzel pada tahun 1897 menemui Sultan Abdul Hamid II untuk meminta izin agar dapat membangun tempat ziarah Yahudi di Palestina, Yerusalem dengan imbalan Gerakan Zionis International akan melunasi seluruh hutang-hutang Turki. (Abdurrahman Al-Maliki: 200-207) Kalau kita lihat sejarah negara-negara Barat sebelum Perang Dunia I menempuh cara dengan memberikan uang sebagai hutang dimana kemudian hutang tersebut mereka melakukan intervensi dan kemudian mendudukinya.

Kedua, sebelum hutang diberikan, negara-negara donor harus mengetahui kapasitas dan kapabilitas sebuah negara yang berhutang dengan cara mengirimkan pakar-pakar ekonominya untuk memata-matai rahasia kekuatan/kelemahan ekonomi negara tersebut dengan dalih bantuan konsultan teknis atau konsultan ekonomi. Saat ini di Indonesia, sejumlah pakar dan tim pengawas dari IMF telah ditempatkan pada hampir semua lembaga pemerintah yang terkait dengan isi perjanjian Letter of Intent (LoI). (Roem Topatimasang, 1999: 9) Ini jelas berbahaya, karena berarti rahasia kekuatan dan kelemahan ekonomi Indonesia akan menjadi terkuak dan sekaligus dapat dijadikan sebagai dasar penyusunan berbagai persyaratan pemberian pinjaman yang sangat mencekik leher rakyat melarat seperti pemotongan subsidi bahan pangan, pupuk, dan BBM yang akhirnya hanya menguntungkan pihak negara-negara donor sementara Indonesia hanya dapat gigit jari saja menelan kepahitan ekonomi.

Ketiga, pemberian hutang adalah sebuah proses agar negara peminjam tetap miskin, tergantung dan terjerat hutang yang makin bertumpuk-tumpuk dari waktu ke waktu.

Keempat, hutang luar negeri yang diberikan pada dasarnya merupakan senjata politik negara-negara kapitalis kafir Barat kepada negara-negara lain, yang kebanyakan negeri-negeri muslim, untuk memaksakan kebijakan politik, ekonomi, terhadap kaum muslimin. Tujuan mereka memberi hutang bukanlah untuk membantu negara lain, melainkan untuk kemaslahatan, keuntungan, dan eksistensi mereka sendiri. Mereka menjadikan negara-negara penghutang sebagai alat sekaligus ajang untuk mencapai kepentingan mereka. Dokumen-dokumen resmi AS telah mengungkapkan bahwa tujuan bantuan luar negeri AS adalah untuk mengamankan kepentingan AS itu sendiri dan mengamankan kepentingan “Dunia Bebas” (negara-negara kapitalis).

Jadi, tujuan pemberian bantuan luar negeri tersebut sebenarnya bukan untuk membantu negara-negara yang terbelakang, melainkan untuk menjaga keamanan Amerika dan negara-negara kapitalis lainnya, atau dengan kata lain, tujuannya adalah menjadikan negara-negara penerima bantuan tunduk di bawah dominasi AS untuk kemudian dijadikan sapi 
perahan AS dan alat untuk membela kepentingan AS dan negara-negara Barat lainnya.

Kelima, hutang luar negeri sebenarnya sangat melemahkan dan membahayakan sektor keuangan (moneter) negara penghutang. Hutang jangka pendek, berbahaya karena akan dapat memukul mata uang domestik dan akhirnya akan dapat memicu kekacauan ekonomi dan keresahan sosial. Sebab bila hutang jangka pendek ini jatuh tempo, dengan pembayarannya menggunakan mata uang Dollar yang merupakan hard currency. Maka dari itu, negara penghutang akan kedulitan untuk melunasi hutangnya dengan dolar AS karena mengharuskan penyediaaan mata uang US tersebut, (untuk pembayaran hutang Swasta, ini akan berdampak pada keterpaksaan pembelian dolar, dimana dolar akan dibeli dengan harga yang sangat tinggi terhadap mata uang lokal, sehingga akhirnya akan membawa kemerosotan nilai mata uang lokal). Untuk hutang jangka panjang, juga berbahaya karena makin lama jumlahnya semakin mencengkram, yang akhirnya akan dapat melemahkan anggaran belanja negara dan membuatnya makin kesulitan dan terpuruk atas hutang-hutangnya. Disitulah negara-negara Donor makin memaksakan kehendak dan kebijakannya yang sangat merugikan kepada Negara. (Abdurrahman al-Maliki, 2009: 204-205)

Pengaruh hutang luar negeri indonesia terhadap ketahanan Nasional ' Ketahanan nasional berisi keuletan dan ketangguhan yang mengandung kemampuan untuk mengembangkan kekuatan nasional dalam menghadapi dan mengatasi segala tantangan. Ketahanan nasional tersebut merupakan perwujudan dari geostrategi bangsa Indonesia ' geostrategi Indonesia bukanlah geopolitik untuk kepentingan politik dan perang tetapi untuk kepentingan kesejahteraan dan keamanan. Namun, dalam pelaksanaan strategi pembangunan khususnya dalam pembangunan ekonomi diperlukan dana yang relatif besar. ' Pokok persoalannya adalah kesulitan dalam pembentukan modal baik yang bersumber dari penerimaan pemerintah maupun dari masyarakat. Maka untuk mencukupinya adalah dengan bantuan luar negeri (hutang luar negeri). ' Dalam kurun waktu 25 tahun terakhir,hutang luar negeri Indonesia telah memberikan sumbangan yang cukup besar bagi pembangunan di Indonesia. namun persoalan pembayaran cicilan dan bunga menjadi beban yang terus menerus harus dilaksanakan. ' ilmuwan memperoleh kesimpulan bahwa hutang luar negeri justru telah menimbulkan perlambatan pertumbuhan ekonomi bagi negara-negara penghutang besar.

Dampak pengaruh negeri indonesia Beberapa dampak hutang luar negeri Indonesia 1. Dampak positif a. Menutup defisit APBN b. Membantu pembangunan negara c. Laju pertumbuhan ekonomi sesuai target 2 . 
Dampak negatif a. Cicilan bunga semaki besar b. Hilangnya kemandirian c. Menghambat pembangunan d. Meningkatkan jumlah pengangguran e. Adanya kesenjangan antara orang di kota dan daerah f. Menyebabkan inflasi g. Negara dianggap negara miskin dan tukang hutang

\section{KESIMPULAN}

Hutang luar negeri setelah dikaji dari berbagai aspek disimpulan sebagai berikut: hutang luar negeri bukanlah sebuah solusi yang tepat dalam pembangunan suatu bangsa dengan bukti-bukti yang sudah diuraikan dalam makalah. Hutang luar negeri adalah bentuk penjajahan secara ekonomi maupun sektor lainya, terbukti pada akhirnya kebijakan hutang luar negeri akan mempengaruhi birokrasi dan kebijakan-kebijakan lainya dalam suatu negara. Ditinjau dari segi ekonomi syariah hutang luar negeri adalah Riba, dan bunga yang ditetapkan sangat mencekik. Dalam hal ini menjadi pintu masuk penghancuran negara negara yang sedang mengalami krisis ekonomi, karena tidak ada unsur saling tolong menolongnya.

Abdurrahaman al-Maliki mengungkap lima bahaya besar yang jelasjelas tampak di depan mata yakni; Pertama, sesungguhnya hutang luar negeri untuk pendanaan proyek-proyek milik negara adalah hal yang berbahaya terutama terhadap eksistensi negara itu sendiri. Akibat lebih jauh adalah membuat masyarakat negara tersebut makin menderita karena ini adalah jalan untuk menjajah suatu negara. Seperti kita mafhum bahwa Mesir dijajah Inggris melalui jalur hutang, begitu pula Tunisia di cengkram Perancis melalui jalur yang sama yaitu hutang. Begitu pula negara Barat membentangkan hegemoninya terhadap negara Utsmaniyah pada akhir masa kekuasaannya melalui jalur hutang. Karena dengan hutang yang menumpuk Daulah khilafah Utsmaniyah yang ditakuti oleh Eropa selama 5 abad, sejak sultan Muhammad al-Fatih menaklukan konstantinopel pada tahun 1453, akhirnya menjadi negara yang lemah, tak berdaya (sebutan daulah khilafah kala itu adalah the Sick man-manusia yang sakit). Dimana akibatnya dimanfaatkan oleh Gerakan Zionis International, Theodore Hertzel pada tahun 1897 menemui Sultan Abdul Hamid II untuk meminta izin agar dapat membangun tempat ziarah Yahudi di Palestina, Yerusalem dengan imbalan Gerakan Zionis International akan melunasi seluruh hutang-hutang Turki. Kalau kita lihat sejarah negara-negara Barat sebelum Perang Dunia I menempuh cara dengan memberikan uang sebagai hutang dimana kemudian hutang tersebut mereka melakukan intervensi dan kemudian mendudukinya. 


\section{DAFTAR PUSTAKA}

al-Maliki, Abdurrahman, (2009), Politik Ekonomi Islam, Bogor: Al Azhar press.

Beberapa penelitian yang mendukung kesimpulan pertama misalnya Kenen (1990), Sachcs (1990) dan Don Busch (1998), sementara yang mendukung kesimpulan kedua antara lain Cohen (1993), Bulow dan Rogof (1990). Sementara itu Chowdurry (1997) menyimpulkan bahwa dampak ini bervariasi dari satu negara dengan negara lain. Lihat Chowdurry, Khorshed dan Amnon Levy. (1997), Hutang Eksternal dan Implikasinya Terhadap Pertumbuhan Ekonomi, Jurnal Ekonomi Pembangunan,Yogyakarta: FE UII, Vol. 2 Nomor 2.

Basri, Faisal, (2002), "Perekonomian Indonesia", Erlangga, Jakarta.

Basri, Yuswar Zainul dan Mulyadi Subri. Keuangan Negara dan Analisis Kebijakan Utang Luar Negeri, Jakarta: Raja Grafindo Persada, 2003.

Boediono, (2008), "Ekonomi Indonesia, Mau Kemana ", (Penerbit Gramedia Pustaka, Jakarta.

Departemen Agama RI, Al'Quran dan Terjemahnya, Bandung; Penerbit CV. Gema Risalah.

Gufron A. Mas'adi, (2002), Fiqih Mu'amalah Kontekstual, cet.1, Jakarta : Raja Grafindo persada.

Hamid, Edy Suandi, (2000) Perekonomian Indonesia Masalah dan Kebijakan Kontemporer, Yogyakarta:UII Press.

HR. Ibnu Majah, Kitab As-Shadaqad, hadis 2419.

Huda, Nurul dkk, (2008), Ekonomi Makro Islam Pendekatan Teoritis, Jakarta: Kencan Prenada Media Group.

Juaro, Umar, (2004), Pertumbuhan Ekonomi, Investasi dan Pinjaman Luar Negeri. Depok: Bappenas, Cides (Center for Information and Development Studies, 2004.

Kaminsky, Graciela L dan Alfredo Preiera, (1996), The Debt Crisis: Lessons of the 1980s for 1990s, Journal of Development Economics, Vol. 50.

Kaminsky, Graciela L dan Alfredo Preiera, The Debt Crisis: Lessons of the 1980s for 1990s, Journal of Development Economics, Vol. 50, 1996.

Karim, Adiwarman, (2007), Ekonomi Makro Islam. Ed 2. Jakarta: PT Rajagrafindo Persada.

Mannan, Abdul, (1992), Teori dan Praktek Ekonomi Islam, PT. Dana Bhakti Wakaf, Yogyakarta.

Misanam, Munrokhim, (2000), Hutang Luar Negeri dan Pembangunan Ekonomi Dalam Perspektif Islam, (Jurnal Asy-Syir'ah No. 7, Yogyakarta.

Nasrun, Haroen, (2000), Fiqh Muamalah, Jakarta: Gaya Media Pratama.

Pasaribu, Chairuman dan Suhrawardi K. Lubis, (1994), Hukum Perjanjian Dalam Islam, Jakarta: Sinar Grafika. 
Qs. Al-Hadid (57) : 11

Qardhawi, Yusuf, (1997), Norma dan Etika Ekonomi Islam, Jakarta: Gema Insani.

Sabiq, Sayyid, (2009), Fikih Sunnah, Jakarta; Dar fath Lili'lami al-Arabiy.

Sarakhsi, Imam, al-Mabsut, juz. XII.

Tulus T.H. Tambunan, (2012), Perekonomian Indonesia, Kajian Teoritis dan Analisis Empiris, cetakan kedua, Bogor : Ghalia Indonesia.

Topatimasang, Roem, (1999), Hutang itu Hutang, Yogyakarta: Pustaka Pelajar.

Todaro, Michel P, (1994), Economic Development, 5th Edition, New york, Longman Publishing.

https:/ / finance.detik.com/ berita-ekonomi-bisnis/3430685/daftarpemberi-hutang-terbesar-ke-pemerintah-ri 